\title{
POLR3K wt Allele
}

National Cancer Institute

\section{Source}

National Cancer Institute. POLR3K wt Allele. NCI Thesaurus. Code C134662.

Human POLR3K wild-type allele is located in the vicinity of $16 \mathrm{p} 13.3$ and is approximately 7 $\mathrm{kb}$ in length. This allele, which encodes DNA-directed RNA polymerase III subunit RPC10 protein, plays a role in the synthesis of small RNAs and in immunity. 